\title{
The Social Commitment of Brazilian Managers: The Concept, a Scale, and an Empirical Study of Corporate Social Responsibility
}

\author{
FILIPE ALMEIDA \\ Faculty of Economics of the University of Coimbra, Coimbra, Portugal
}

FILIPE SOBRAL

Brazilian School of Public and Business Administration of the Getúlio Vargas Foundation (EBAPE/FGV), Rio de Janeiro, Brazil

\begin{abstract}
The purpose of this study is to analyze the attitudes of Brazilian managers toward Corporate Social Responsibility, defined as their willingness to simultaneously meet the economic, legal, and ethical commitments that bind business companies to society. A Managers' Social Commitment Index (SCI) is proposed and a new scale is presented and confirmed as a reliable research instrument in a field study involving 252 Brazilian business managers. Results revealed that managers prioritize economic commitment, even though as they get older and more experienced they tend to sacrifice this commitment to comply with the law. Women showed greater willingness to integrate ethical interests in management decision making, revealing a higher degree of social commitment.
\end{abstract}

RESUMEN. Este estudio tiene por objeto analizar las actitudes de los gerentes brasileños cuanto a la Responsabilidad Social Corporativa, definida como su buena voluntad en cumplir, simultáneamente, las obligaciones legales y éticas que comprometen a las empresas con la sociedad. Consecuentemente, se propuso un Indice de Compromiso Social de los Gerentes (SCI-Manager's Social Commitment Index), confirmándose también una nueva escala que se utilizó como instrumento de investigación confiable, 
implementada en un estudio de campo de involucró a 252 gerentes brasileños. A pesar de demostrar que los gerentes priorizan los compromisos económicos, los resultados obtenidos también indicaron que, a medida que adquieren más edad y experiencia, ellos tienden a sacrificar este compromiso con miras a cumplir rigurosamente la ley. Las mujeres demostraron tener más buena voluntad en integrar los intereses éticos en la toma de decisión gerencial, revelando disponer de un grado más alto de compromiso social.

RESUMO. O objetivo do presente estudo é analisar as atitudes dos gerentes brasileiros no que concerne à Responsabilidade Social Corporativa, definida como a vontade que têm em atender simultaneamente os compromissos legais e éticos que vinculam as empresas comerciais à sociedade. É proposto um Indice de Compromisso Social dos Gerentes (SCI-Manager's Social Commitment Index), além de ser apresentada uma nova escala, confirmada como um confiável instrumento de pesquisa em um estudo de campo que incluiu 252 gerentes brasileiros. Os resultados revelaram que os gerentes dão prioridade aos compromissos econômicos, porém, à medida que ficam mais velhos e mais experientes, tendem a sacrificar esse compromisso visando a adequação legal. As mulheres mostraram vontade maior de integrar os interesses éticos ao processo decisório gerencial, revelando um nivel mais elevado de comprometimento social.

KEYWORDS. business ethics, corporate social responsibility, social commitment of managers

\section{INTRODUCTION}

Corporate Social Responsibility (CSR) has become, in the past decades, one of the most fertile and controversy interdisciplinary fields of research in organizational studies. It has inspired ideological arguments and provided multiple approaches on the discussion about the roles that for-profit corporations and the State should play in society. The public debate on CSR has grown substantially since the 1950s, especially in the United States, propelled by the increasing questioning of the ethics underlying business practices among certain large-scale business monopolies (Boatright, 2003). This critical stance, which demanded corporate philanthropy and contested the alleged social injustice of certain corporate practices in the first half of the 20th century, later gave way to the development of systematic debate on business ethics and corporate social responsibilities (Kreitlon, 2004). Thus, underlying the debate on CSR is an implied critique of business 
corporations and their role as relevant social agents, in parallel with a corporate discourse and practice that has evolved partly as a response to social pressures (e.g., from institutions, media, and civil society).

Since then, theoretical debates and empirical research on CSR have flourished. Corporate practices have been studied and an attempt was made to find a link between social and financial performance (Simpson and Kohers, 2002; Moore, 2001; Roman Hayibor, and Agle, 1999; Verschoor, 1998). Yet, such link has not thus far been established (Bakker, Groenewegen, and Hond, 2005), as multiple interpretations of the CSR concept endure among authors (Godfrey, Hatch, and Hansen, 2010). A special attention was also given to how managers' personal values relate to CSR strategies, with some authors arguing that personal morality and belief systems actually influence the way companies approach CSR and their commitments toward society (Sirsly, 2009; Shafer, Fukukawa, and Lee, 2006; Hemingway, 2005). Recent trends identify CSR as a product of institutional forces (Angus-Leppan, Metcalf, and Benn, 2009) that drive different levels and patterns of corporate social commitment depending on how institutional and political conditions articulate in each country with the specific historical role of business and its relationship vis-à-vis society (Blasco and Zolner, 2010; Xu and Yang, 2009; Puncheva-Michelotti, Michelotti, and Gahan, 2009).

Besides these trends in literature, studies show that companies engaged in CSR-related activities long before the concept of CSR was framed (Tengblad and Ohlsson, 2009) as a natural corporate response to increasing competition in global and other more demanding markets. Tengblad and Ohlsson (2009: 666), in business internationalization processes, observed a shift from "traditional regulation of economic capitalism mainly by political action to a situation of regulation through ethical coercion: companies are persuaded to adapt to external moral standards and have to put their reputation as pledge." As such, CSR appears to be often strategically driven, as companies tend to show higher levels of social performance in highly competitive industries (Fernández-Kranz and Santaló, 2010). CSR strategy seems to be oriented, among other factors, by fiduciary duties toward shareholders and the physical and social proximity to those communities where the company undertakes significant social action (Frederiksen, 2009). These choices have a clear strategic orientation, revealing a change from a short-term approach to a more long-term sustainable growth. However, they still suggest that considerable room is left for management discretion as to how CSR policies and practices are implemented.

As strategic decision makers, top managers' choices are not always aligned exclusively with the interests of shareholders (Eisenhardt, 1989); rather, they tend to reflect the arbitrary nature of their personal interests and desires (MacLagan, 1998), system of beliefs, view of the world and of human relations, conceptions of economy, and even political ideology. Thus, the difference between corporate discourse and practice can be partly 
explained by managers' personal understanding of the concept, implications, and limits of CSR, including its theoretical ramifications such as corporate citizenship, corporate governance, sustainable development, or stakeholder orientation. It appears important, therefore, to study the reasoning of managers and company leaders on the subject of CSR, thus seeking a complementary approach to the phenomenon, not based on business practices but on the social orientation of corporate leaders who define and influence CSR.

This study is an attempt to remedy this apparent gap in CSR research, aiming to gauge Brazilian business managers' social commitment; that is, their willingness to adopt a socially responsible management practice. Brazil has a history of public, academic, and political debate on CSR that goes back several decades. Ever since the creation of the Association of Christian Business Leaders (ADCE) in 1960, CSR has progressively gained visibility as a topic of discussion among opinion makers, and many researchers have devoted themselves to the theme (Puppim de Oliveira, 2005; Karkotli and Aragão, 2005; Tenório, 2004; Thiry-Cherques, 2003; Froes, 2001). Ashley (2005) highlighted how the pioneering works of the ADCE in promoting debate on CSR "deeply determined the relevance of questioning the social dynamics of business corporations in Brazil" (69). Founded in 1998, the ETHOS Institute of Businesses and Social Responsibility has quickly become one of the most important forums of management practice, discussion, and questioning among businessmen. As an association of private companies, the ETHOS Institute is currently one of the most influential sources of reflection and dissemination of CSR practices and ideas in Brazil, defending the need for businesses to develop lasting and mutually beneficial ties with their multiple stakeholders. For this reason, it seems pertinent to study the mindset of Brazilian managers with respect to CSR and to investigate whether such debate has fostered any real change in mentality.

As such, this research study on CSR in Brazil focuses on the attitudes of business managers as central agents in the adoption of corporate policies and practices aligned with society's expectations and needs. A new scale for measuring this attitude is presented and tested, built on the assumptions of a specific CSR conception and inspired by the methodology developed by Aupperle, Carroll, and Hatfield (1985) to measure corporate social responsibility orientation.

\section{CORPORATE SOCIAL RESPONSIBILITY: A REVISED MODEL}

\section{The CSR Concept}

At the heart of the debate on CSR lies the issue of what drives business performance and practice. Classic liberal views argue that corporations must pursue profit as their exclusive goal, contributing to social well-being by 
paying taxes, the appropriate public policy instrument that actually allows a fair social distribution of wealth (Friedman, 1962). The significance of CSR increased progressively at the same time that the liberal vision was being challenged by authors who place business responsibility above profit and strict compliance with the law. This broader conception of business objectives argues that corporations must contribute actively to social development, not simply through the economic profit they generate but also by having a direct intervention in the resolution of social problems and investing in the prevention of harmful effects their activity may have on collective well-being (Davis, 1973). CSR thus implies the obligation of companies to consider social impacts when defining their goals and strategies, committing themselves to the society on which they depend.

The conception of CSR evolved alongside with the deep social, political, and economic changes that characterized the 20th century. ${ }^{1}$ At first identified simply with philanthropic donations or good corporate governance practices, CSR came to play an important legitimating role of business conduct, promoting the view of corporations as "moral agents" subject to ethical appraisal, having rights and obligations, being accountable for their actions and subject to liability beyond legal requirements. During the past decades, the debate on CSR has included the concepts of "sustainable development," as a reflection of concerns regarding the environmental impact of business activity, and "stakeholders" as enlightening the multiplicity of interests that intersect with those of corporations. With the emergence of these new demands, the scope of business responsibilities expanded, albeit without any stable consensual theory or understanding of corporate duties toward society (Godfrey et al., 2010). Currently, definitions of CSR usually encompass the ideas of philanthropy, corporate governance, ethics, sustainable development, and orientation toward stakeholders.

\section{Carroll's CSR Model: Virtues and Weaknesses}

Despite the agreement among authors and opinion makers as to what CSR implies in terms of corporate behavior in free markets, few have actually presented a coherent theory that clearly outlines the sources of CSR and how they translate in practical management choices and strategic orientations (Godfrey et al., 2010). The most referenced attempt to provide an answer to this issue is the famous model presented by Carroll in 1979, recently applied in Brazil (Pinto, Pereira, and Lara, 2004). Carroll's model structure and reasoning has survived for the past 30 years, remaining widely accepted by the scientific community (Bakker et al., 2005; Acar, Aupperlle, and Lowy, 2001). The author sets out four specific types of social responsibility for business companies, grounded in society's expectations with regard to corporate performance: economic, legal, ethical, and philanthropic responsibilities. Figure 1 presents Carroll's model. 


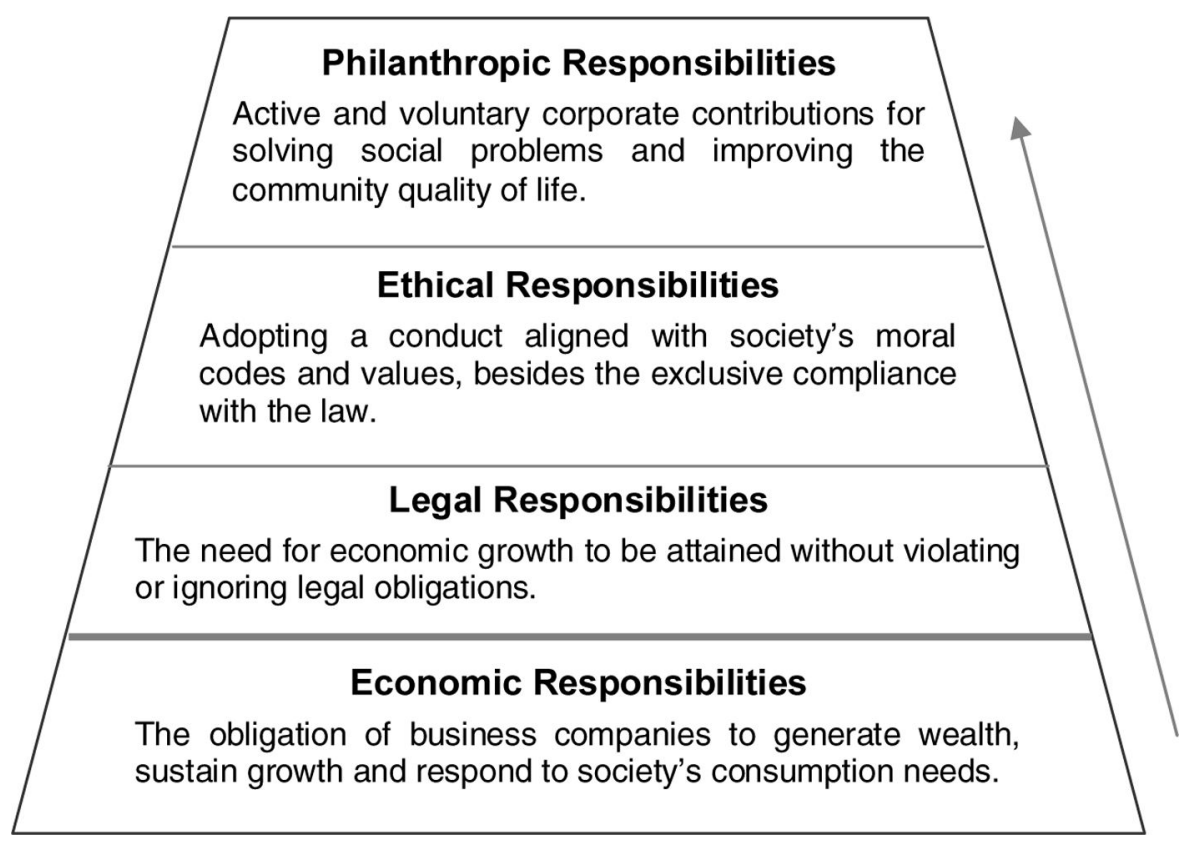

FIGURE 1 Corporate social responsibilities (adapted from Carroll, 1979, 1999).

This pyramid structure highlights Economic responsibility as the foundation of all other responsibilities, which in turn are assumed by corporations in a priority sequence as suggested by the ascending order presented in Figure $1 .^{2}$ The classical conception of CSR sets the voluntary commitment of business persons above strictly economic or legal obligations (McGuire, 1963), which highlights, under Carroll's model, Ethical and Philanthropic responsibilities. Ethical responsibility is related to a conduct that, although not imposed by law, is socially desirable and ethically justifiable, whereas Philanthropic responsibility implies a direct corporate involvement through donations or transfer of resources in initiatives aimed at improving the community's well-being and promoting social development (Ferrell, Fraedrich, and Ferrell, 2002). Although some authors question the validity of the dichotomy set up by Carroll between the economic and the social dimension of CSR (Mitchell, Agle, and Wood, 1997), his proposals were the basis for some of the most significant later theoretical developments, such as the works of Wartick and Cochran (1985) and Wood (1991).

Three main innovative ideas can be drawn from Carroll's reasoning: First, his explicit reference to economic commitments as being part of corporate social responsibility. Although a distinction is suggested between the multiple responsibilities, Carroll does not oppose the profit-seeking goal to the remaining dimensions, challenging the view that sees profit as a source of corporate egoism that causes harmful social dysfunctions. Second, the 
inclusion of legal responsibility in the model challenges the classical, yet dominant, view that establishes the law as boundary after which social responsibility engages (McGuire, 1963; Walton, 1967). Carroll understands social responsibility in a wider sense, arguing that it cannot exclude the obligation to comply with the law, as it is the expression of a social desire for regulation. Last, although the pyramidal diagram suggests a specific sequence of adherence to social responsibilities, Carroll stated that these responsibilities can - and should-be met simultaneously. What may vary is the degree of compliance in management practice, depending on the size of the company, its management philosophy, its corporate strategy, and the characteristics of the industry or the economic environment (Carroll, 1991). Thus, companies cannot renounce any one responsibility in order to comply with another and should seek to reconcile all their social commitments. Essentially, this conception of CSR emphasizes the need for companies to attain their economic goals, complying with the law and at the same time embracing commitments that entail ethically acceptable conduct and an interventionist role in improving societal quality of life.

Although widely disseminated among academics throughout the world, Carroll's model (1979) is not still completely satisfactory. One of its weaknesses is the rigidity of the ascending, unidirectional sequence of responsibilities compliance. This conception, although it does not aim at legitimizing the preference of certain responsibilities over others, suggests a hierarchy of priorities that appears to distort the equitable basis of Social Responsibility. In addition, it implies the overlap of responsibilities while ignoring other forms of interdependence and interaction between them. The model also appears to confuse principles and concrete actions by including Philanthropic responsibility. Philanthropy, as currently understood, consists of a voluntary transfer of resources from civil society to benefit those in direct need or in order to promote social change (Kisil, 2005). However, this contribution from civil society is actually a behavior, i.e., an expression of certain principles, beliefs or values. Ethical responsibility, inspired by rational duty and, possibly, by the feelings of love for humanity and generosity that define the essence of philanthropy (Houaiss and Villar, 2002), presumes the moral commitment that complements the remaining ones (economic and the legal) being a philanthropic action only as one of its possible expressions. Therefore, philanthropy, while a reflex of sentiments currently understood as a transfer of resources, must not be regarded as a corporate obligation. It should, instead, be held as but one of the possible practical expressions of ethical responsibility. ${ }^{3}$

\section{Corporate Social Commitments: Re-Defining CSR}

Despite the several available definitions and multiple discussions surrounding CSR, the concept still appears to contain ambiguities that hamper the analysis, understanding, and comparison between different authors' 
empirical findings and conclusions (Bakker et al., 2005). It seems reasonable to accept that corporate responsibilities include a diverse set of obligations frequently demanding compromises between diverging, or even conflicting, interests. It is the search for this fragile balance between interests that defines the central challenge of CSR. Thiry-Cherques (2003) acknowledged that the challenge corporations face today lies in reaching an equilibrium that will avoid both the excesses of immoral capitalism and the discourse that defends CSR as a way of demanding from companies' practices and intentions at odds with their economic competence and mission, endangering the very spirit of capitalism that can foster progress and social development. As Aguilar (1996) agreed, an ethical company is one that has gained the respect and trust of its employees, customers, suppliers, and investors, reaching an acceptable balance between its economic own interests and the interests of all those affected by its decisions and actions.

Inspired by the original contributions of Carroll (1979), Wartick and Cochran (1985), and Wood (1991), a new approach to CSR arises, based on corporate duty to society. CSR is defined as a combination of the three types of commitment that bind corporations to society: economic, legal, and ethic (as presented in Figure 2).

As presented, CSR is identified with the set of obligations deriving from the corporation's economic, legal, and ethical commitments to society. These three types of commitment represent the three established sources of social responsibility that guide the principles of corporate performance. CSR thus implies a continuous effort to articulate policies, strategies, and actions in order to carry out the positive and negative duties (of action and omission, respectively) suggested by economic goals, ethical principles, and legal requirements. The designations of these commitments identify the motive

ETHIC

(moral values and principles of ethical conduct)

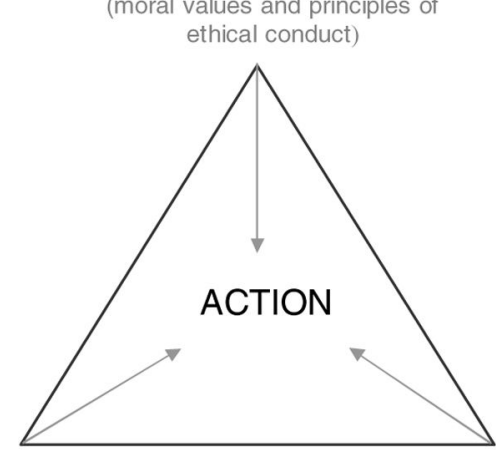

(foundation of business existence that assures continuity)

LEGAL

(norm imposed by law)

FIGURE 2 Corporate social commitments. 
of the obligations that underlie each one, with philanthropy being understood as an action, not as a guiding principle of corporate performance.

Economic responsibility refers to the central goal of business activitythat which justifies its existence and assures its survival and sustainability. This responsibility is defined as the obligation to supply society with high-quality goods and services, investing in innovation and seeking a sustainable profit that allows business growth and meets shareholders' legitimate expectations.

Legal responsibility embodies the social obligation of complying with legislation. In democratic regimes, the law derives from a collective desire for regulation ratified by society. The existence of such laws, however, is no guarantee of compliance. Although sanctions usually inhibit transgressions, corporations can still freely choose to comply or not with the law in a countless number of circumstances. And it is precisely that freedom that makes it a source of corporate responsibility.

Last, ethical responsibility is the duty to act in accordance with moral principles aligned to social values. This responsibility implies adopting acceptable ethical conduct that, while not imposed by law or economic goals, is based on a disposition to integrate in corporate policies and strategies a set of serious concerns that can prevent possible damage caused by business action, considering as well its positive contribution for social well-being and human development. CSR's ethical dimension is the one that requires the greatest justifying effort, given its natural ambiguity and the variability of the arguments in its favor (Carroll, 1991). Thiry-Cherques (2003) recognized this complexity, clarifying that "moral responsibility is not coercive, negotiable or evident," being "the xxx only that does not admit misunderstandings or evasion" (34). The repression instruments of response to non-compliance with economic and legal responsibilities are more visible and consensual and thus more effective. There is widespread agreement on the nature and limits of these obligations and their boundaries are not usually contested. Ethical responsibility, however, constitutes an obligation imposed exclusively by moral criteria, where transgression is inhibited by an imperative of the conscience or fear of moral reprove by others.

As described, and in accordance with the CSR concept, corporate performance should result from the relative importance given to each of its responsibilities; that is, the influence of their underlying principles on policies, strategies, and business practices. Although CSR suggests, as a desirable strategy, the search for equilibrium between the three social commitments, it is naturally expected that economic commitment, as the one that justifies the existence and survival of the company, should be the most highly valued by management and business leaders. Besides, unlike economic and legal responsibilities, whose agents and institutions most interested in its compliance are well known, ethical responsibility makes the corporation accountable to society as a whole and, ultimately, to the consciousness of whoever is bound to this responsibility. Ethical responsibility aims to 
overcome the insufficiencies of an egocentric management conception that sets profit as an end toward which any means are justified, with no regard for the collateral impacts of business action and the deep interdependence between the corporation and the rest of the world. This managerial attitude, identified with an individual egoism that only values self-interest, with no consideration for ethical commitments, gives rise in extreme cases to socially unacceptable conduct and to mistrust, thereby compromising the survival of the organization itself. As Thiry-Cherques (2003) pointed out, " ethical commitment is a construction of reason that considers egoism as part of human nature," with ethics having shown in different ways that "morally legitimate conduct is of one's interest, of rational persons' interest, that is of one's selfish interest to overcome egoism" (40).

\section{EMPIRICAL STUDY}

\section{Data Collection}

Data was collected with a structured questionnaire filled out by graduate students enrolled in MBA and Executive Business Programs in Rio de Janeiro and in São Paulo. The questionnaire was given during classes with the presence of the researcher who stressed that responses would remain anonymous and that the data would be treated as an aggregate in order to prevent social desirability bias.

\section{Sample}

Considering that the research was aimed at managers and did not impose restrictions on the industry or on specific corporate conditions, the sample was selected based on accessibility. To improve research validity, the sample was restricted to Brazilian native managers working in private for-profit companies and who had at least three years of professional experience (to assure a reasonable knowledge of the market and of the economic and social implications of business decisions). Thus, the final sample includes $252 \mathrm{MBA}$ students who met these requirements and completed the questionnaire entirely. The managers come from many areas of corporate management (from marketing to human resources or finance), working mostly in service (76\%) and manufacturing (15\%) companies. The sample included more men (58\%) than woman, with an average age of 33, and 11 years of professional experience.

\section{The New Scale of Managers' Social Commitment: Validation and} Contents

For assessing managers' attitude toward CSR, a new scale was developed, inspired by the questionnaire created by Aupperle and colleagues (1985) 
to measure corporate social orientation, based on Carroll's CSR model (1979). ${ }^{4}$ In the authors' original version, respondents were required to assign, in accordance with their preference, 10 points to each of 20 sets of 4 sentences pertaining to managerial action principles underlying the four CSR dimensions proposed by Carroll (1979). In the new version, two fundamental changes were made. First, Philanthropic responsibility was eliminated, and only three orders of responsibility were retained: economic, legal, and ethical. As stated previously, philanthropic action properly belongs to the ambit of free choices and not to that of social obligations. Second, instead of grouping in each set merely general managerial principles, a comparison was forced between concrete management practices, decisions, and goals, thereby compelling respondents to choose between usually conflicting alternative actions and making the questionnaire closer to everyday managerial practice. Therefore, all the items in this scale are totally new.

In order to prevalidate this new scale, the questionnaire was submitted to external evaluation and subjected to scrutiny for inconsistencies and omissions through a pretest. As such, a first draft of the scale was submitted to specialists in the topic, and their suggestions were incorporated in an improved draft of the research instrument. This phase enabled improvements to be made in the language used for certain items and enabled conceptual redundancies to be eliminated. A pretest was then carried out on 25 students of a graduate course (all with relevant professional experience) at an institution of Higher Education in Rio de Janeiro. During this phase, additional adjustments were made to the language of the questionnaire, and the average duration of each answer was evaluated. Based on this, an optimized final version of the scale for measuring managers' attitude toward CSR was obtained.

The final questionnaire consisted of a forced choice scale comprising 12 sets of 3 items, where respondents are required to allocate 10 points to each of the sets according to the degree of relative importance they attach to each item. The three items in each set describe concrete business actions or goals and correspond to the three corporate social commitments. So that the comparative analysis of the items in each set could translate personal preferences as close as possible to management practice, an effort was made to maintain coherence among the items in each set, avoiding mixing goals with practices or management philosophies with concrete actions. The items were, therefore, grouped according to a coherent criterion, covering general business objectives, management practices, and actions directed at specific stakeholders (employees, customers, society, and the environment). This format aimed at covering the different areas of decision making that embodies corporate management.

Regarding the items selected for the scale and its formulation, an attempt was made to include only those that did not suggest a socially more desirable answer, thereby avoiding leading the answer toward a solution distant from the respondent's personal preference. This format of assessing 
attitudes toward CSR offers significant advantages over other existing instruments. The main advantages of this new scale are:

- Aiming to assess how managers reconcile the three commitments underlying CSR, a forced choice scale seems to be an appropriate way to measure attitude toward CSR, as it represents the real-life management practice of facing the dilemma of having to choose among mutually exclusive options.

- By asking managers to allocate 10 points over 3 options, the scale forces them to take a stand with regards the three CSR underlying commitments, clarifying the hierarchy of their preferences and avoiding the tendencycommon in scales of importance-to score all options the same.

- By not inquiring the degree of importance attributed to each action or goal, but rather merely asking respondents to allocate 10 points over the options, the scale also reduces the socially desirable answer that usually conceals respondents' true views, as respondents did not have to declare the absolute importance they confer to the options, but only their relative importance.

- There was also a concern to group in each set management practices and goals that could in some way be compared among themselves, thereby addressing issues related to the main stakeholder groups. This aspect of the study reinforces the theoretical coherence and relevance of the scale in assessing CSR. ${ }^{5}$

The items of this new scale are presented in Table 1; the social commitment underlying each item is identified in brackets.

\section{The Managers' Social Commitment Index}

Based on the new scale, we propose the managers' Social Commitment Index (SCI). This quantitative indicator attempts to measure managers' social approach to business, representing the extent managers are willing to conduct business in a socially responsible way and balancing managerial practice in accordance with the three corporate social commitments: economic, legal, and ethical. Thus SCI represents the degree of social commitment that each manager is willing to assume, varying on a scale from 0 to 10 points and calculated as follows:

1. For each respondent, the average value attributed to the items representing each of the three social commitments is computed.

2. Next, we compute the difference between the greater and the lesser average found among those three values (this difference represents how distant is the respondent's decision from the socially optimal point, i.e., the desirable equidistance between commitments). ${ }^{6}$ 
TABLE 1 Managers' Social Commitment Scale

Items of the Scale of Attitude to CSR

A. Maximize return on investment (ECR1)

B. Comply with legislation (LER1)

C. Pay fair wages (ETR1)

A. To do honest and transparent advertising of products (ETR2)

B. Develop marketing campaigns to capture new customers (ECR2)

C. Respect and comply with legal norms regulating competition (LER2)

A. Purchase more efficient technology (ECR3)

B. Purchase environmentally friendly technology (ETR3)

C. Comply with environment protection legislation (LER3)

A. Comply with work-related legislation (LER4)

B. Reward the performance of the most efficient employees (ECR4)

C. Offering job opportunities to the disabled (ETR4)

A. Monitor and minimize the negative impact of business activity on the environment (ETR5)

B. Apply legal norms on health, safety, and security in the workplace (LER5)

C. Implement management procedures designed to improve operational efficiency levels (ECR5)

A. Carry out market surveys to learn about consumer habits (ECR6)

B. Disclose to customers the imperfections and risks of products (ETR6)

C. Comply with the legislation on business transactions (LER6)

A. Always act in accordance with legal demands and court decisions (LER7)

B. Fund social projects to fight poverty (ETR7)

C. Invest in research and development of new products (ECR7)

A. Meet deadlines for tax payments (LER8)

B. Meet the plan of investment in new processes to reduce operational costs (ECR8)

C. Meet wage and benefit payment deadlines (ETR8)

A. Make decisions in order to meet shareholders' expectations (ECR9)

B. Make decisions in order to comply with the law (LER9)

C. Make decisions in order to meet society's expectations (ETR9)

A. Assess performance based on profit sustainability (ECR10)

B. Assess performance based on compliance with legal norms (LER10)

C. Assess performance based on contribution to social well-being (ETR10)

A. Fund social projects for child education (ETR11)

B. Accept and comply with any court decisions (LER11)

C. Develop innovative marketing campaigns (ECR11)

A. Develop initiatives that promote employee's environmental awareness (ETR12)

B. Invest in training programs to increase productivity (ECR12)

C. Organize training programs to promote workers' awareness of trade legislation (LER12)

ECR: Economic Responsibility; LER: Legal Responsibility; ETR: Ethical Responsibility.

3. For the SCI to be a positive indicator of social commitment, and since the score limits for each item vary from 0 to 10 points, each manager's SCI will be found by subtracting the difference found in the preceding step from the maximum value of social commitment, which will, in this case, be 10. Therefore, the closest a manager's SCI is to 10, the higher his social commitment.

The SCI thus provides a simple way of quantifying each manager's social commitment and, moreover, a way to compare them. This procedure also 
avoids, as theory suggests, judgments as to the relative importance of the three social responsibilities inherent to the commitments. Equal weight is given to the three responsibilities, assuming that the undervaluation of any of them inevitably — and with equal intensity—reduces a manager's appetence for reaching an equilibrium of commitments that defines a socially responsible management.

\section{Data Analysis}

To validate the proposed scale, a confirmatory factor analysis was conducted using the statistical package LISREL 8.3 (Joreskög and Sörbom, 1989). Data were submitted as a correlation matrix, adopting the generalized least squares estimator. Given that the items in each set were correlated among themselves (being a forced choice scale) error correlation between the items in each set was freed for analysis under the proposed structural model.

\section{RESULTS}

\section{Scale Validation}

To evaluate unidimensionality and convergent validity of the proposed scale (36 items included in 12 sets of 3 items that measure the respondents' attitude toward three social responsibilities), a confirmatory factor analysis (CFA) was undertaken. The structural model of the three social responsibilities revealed a satisfactory adjustment to the data $\left(\chi_{(555)}^{2}=716.1 ; \chi^{2} / \mathrm{gl}=1.29\right.$; RMSEA $=$ 0.037), however, several goodness of fit indexes were below 0.9 (GFI $=0.86$; 0.86; $\mathrm{AGFI}=0.84$; $\mathrm{CFI}=0.97)$, suggesting the possible existence of certain limitations in the model (Byrne, 1998; Diamantopoulos and Siguaw, 2000). In fact, although the factor loadings of the structural model were all statistically significant at $1 \%$, the coefficients of determination of each of the items $\left(\mathrm{R}^{2}\right)$ presented, in some cases, values between 0.1 and 0.2 , which is usually considered insufficient (Fornell and Larcker, 1981). Thus, to increase the validity of the model, the sets containing items with $\mathrm{R}^{2}<0.20$ were excluded. The final model, comprising 8 sets of 3 items each, revealed a very good adjustment, supported by all the indicators $\left(\chi_{(225)}^{2}=254.6 ; \chi^{2} / \mathrm{gl}=1.13\right.$; RMSEA $=0.037$; GFI $=0.92 ; \mathrm{AGFI}=0.90 ; \mathrm{CFI}=0.99)$, and a factor structure with factor loadings over 0.4 . Table 2 presents the factor structure of the previous structural model.

The reliability of the constructs was measured by the Cronbach's alphas $(\alpha)$ of each of the subscales representing the three social responsibilities, which suggested that these subscales present good internal consistency, with $\alpha$ close to or above 0.8 . This means that the items included in the scale of each CSR dimension are related with the same theoretical construct. 
TABLE 2 Factor Structure of the Final Model

\begin{tabular}{|c|c|c|c|}
\hline & $\begin{array}{l}\text { Economic } \\
\text { responsibility }\end{array}$ & $\begin{array}{l}\text { Legal } \\
\text { responsibility }\end{array}$ & $\begin{array}{l}\text { Ethical } \\
\text { responsibility }\end{array}$ \\
\hline ECR1 & $0.51(9.78)$ & & \\
\hline ECR4 & 0.55 (10.09) & & \\
\hline ECR5 & $0.48(8.95)$ & & \\
\hline ECR7 & $0.62(11.10)$ & & \\
\hline ECR9 & $0.57(10.72)$ & & \\
\hline ECR10 & $0.72(13.76)$ & & \\
\hline ECR11 & $0.65(12.01)$ & & \\
\hline ECR12 & $0.55(10.18)$ & & \\
\hline LER1 & & $0.59(10.65)$ & \\
\hline LER 4 & & $0.44(8.53)$ & \\
\hline LER5 & & $0.56(9.32)$ & \\
\hline LER7 & & $0.56(10.51)$ & \\
\hline LER9 & & $0.54(10.67)$ & \\
\hline LER10 & & 0.71 (13.08) & \\
\hline LER11 & & $0.62(11.29)$ & \\
\hline LER12 & & $0.51(9.11)$ & \\
\hline ETR1 & & & $0.54(9.71)$ \\
\hline ETR4 & & & $0.49(8.56)$ \\
\hline ETR5 & & & $0.55(9.33)$ \\
\hline ETR7 & & & $0.60(11.14)$ \\
\hline ETR9 & & & $0.57(10.70)$ \\
\hline ETR10 & & & 0.68 (12.91) \\
\hline ETR11 & & & $0.66(12.24)$ \\
\hline ETR12 & & & $0.56(9.24)$ \\
\hline$\alpha$ & 0.802 & 0.788 & 0.786 \\
\hline
\end{tabular}

Standardized factor loadings obtained from Lisrel output are shown. The estimation method used to perform the CFA was Generalized Least Squares.

\section{Analysis of Managers' Social Commitment}

As described, after the systematization of items and some discussion as to its relevance with several specialists, the scale's theoretical validity was confirmed by $\alpha$ values and by confirmatory factor analysis, suggesting that the 24 items retained in the scale are adequate indicators of management attitudes toward each social responsibility. These indicators were computed by averaging the points allocated by each respondent to the items retained in the subscale of each responsibility, representing a measure of the relative importance given by managers to each of the three proposed dimensions of CSR. As expected, a preliminary analysis of the new indicators shows that economic responsibility scores higher (3.94) than legal responsibility (3.18) and ethical responsibility (2.87). Descriptive statistics and correlations are presented in Table 3.

Results suggest that, when faced with the need to choose between different corporate social commitments, managers tend to place greater value on the economic responsibility. This result is not surprising, since the economic purpose of a private business corporation is the basis of its existence, 
TABLE 3 Descriptive Statistics and Correlation Matrix

\begin{tabular}{lcccccc}
\hline & Mean & SD & Median & ECR & LER & ETR \\
\hline Economic Responsibility (ECR) & 3.94 & 0.82 & 3.88 & 1 & & \\
Legal Responsibility (LER) & 3.18 & 0.66 & 3.13 & $-0.52^{* *}$ & 1 & 1 \\
Ethical Responsibility (ETR) & 2.87 & 0.74 & 2.88 & $-0.64^{* *}$ & $-0.32^{* *}$ & 1 \\
Social Commitment Index (SCI) & 8.45 & 0.86 & 8.55 & $-0.57^{* *}$ & $0.15^{*}$ & $0.58^{* *}$ \\
\hline
\end{tabular}

The correlation coefficients presented.

${ }^{* *}$ Correlation is significant at the 0.01 level (2-tailed).

${ }^{*}$ Correlation is significant at the 0.05 level (2-tailed).

the guarantee of its survival and often the main criterion by which its performance is assessed. Managers are those responsible for the corporation's accountability toward society, customers, and, above all, shareholders. It was expected that their choices would reflect the fact that, first and foremost, they serve the interests of the shareholders on whom they depend. Thus, managers develop attitudes toward legal and ethical responsibilities essentially in opposition to economic commitment, which does not usually allow the same disruption as the other dimensions of CSR.

To understand the association between these CSR dimensions, Pearson correlation coefficients were computed. The resulting correlations between three responsibilities confirm this antagonism, mirroring the results of the original study by Aupperle and colleagues (1985) and later research (Ibrahim and Angelidis, 1993). The economic dimension presents a statistically significant negative correlation to the legal and ethical dimensions of CSR $(r=-0.52$ and $r=-0.64$, respectively), confirming the idea that, when faced with corporate social commitments, managers value economic responsibility by opposition to the remaining responsibilities. On the other hand, contradicting earlier results (Aupperle et al., 1985; Ibrahim and Angelidis, 1993), LER and ETR also present a negative correlation $(\mathrm{r}=-0.32)$, probably due to the peculiar nature of a forced choice scale. ${ }^{7}$

As for the Social Commitment Index (SCI), it is, as explained, a quantitative indicator of each manager's distance from the ideal managerial attitude that seeks absolute compromise between the demands and appeals of different social responsibilities. Although this value is of little significance when taken alone, on the scale of 10 possible points, managers' SCI presents an overall average of $8.45 .^{8}$ The distance of this average SCI value in the sample with respect to the maximum possible value of 10 (1.55) is the average of the maximum differences between the more distant attitudes of each manager. As shown on Table 3, the three dimensions of CSR show statistically significant correlations with SCI. However, the direction and intensity of these correlations provide better understanding of the role each dimension has in the overall SCI. There is a negative correlation between SCI and ECR $(r=-0.57$, sig. $<0.01$ ), which suggests that managers' SCI increases at the expense of 
ECR. On the other hand, there is a strong positive correlation between SCI and ETR $(r=0.58$, sig. $<0.01)$, suggesting that ETR is the CSR dimension that contributes most to improving managers' SCI. That is to say, ECR is confirmed as a priority within managers' preferences and ETR is confirmed as having a critical importance for developing a socially responsible management attitude. However, there is also a weak, yet significant, correlation between SCI and LER $(r=0.15$, sig. $<0.05)$, which suggests that greater orientation toward compliance with legal obligations is also associated with greater social commitment from managers. In sum, the main results suggest that, to comply with legal or ethical commitments, managers choose primarily to sacrifice the corporate economic commitment.

To analyze the influence of several demographic variables on the social commitment of the respondents, a one-way ANOVA was conducted. As shown on Table 4, results reveal that the only statistically significant difference between SCI and the demographic factors tested was gender. Table 4 callout According to the results of the analysis of variance, women's SCI is significantly higher than men's (8.65 vs. 8.31, sig. $<0.01)$, suggesting that, in business environment, women are more likely than men to be open to compromises between social responsibilities, revealing a more socially responsible management attitude.

\section{The Influence of Demographic Factors in Managers' Social Commitment}

The detailed analysis of the influence of individual and organizational demographic variables on managers' attitude toward the three CSR dimensions also reveals interesting results. The completed results of the analysis of variance between groups are presented in Table 5 .

Results suggest that gender plays an important role on managers' attitude toward two of the three CSR dimensions, confirming statistically significant differences between men and women with regard to ETR and LER. ETR is significantly higher in women's set of social responsibility preferences (3.07 vs. 2.77, sig. $<0.01$ ), unlike LER, which is significantly higher among men (3.30 vs. 3.09, sig. $<0.05)$. Results suggest that men have a more legalistic management orientation than women, while the latter are more willing than men to undertake ethical commitments, such as those underlying corporate ethical commitments toward social development, environment preservation, employee well-being, and transparency in dealings with customers. Interestingly, no significant differences were found between men and women regarding ECR.

The results also suggest that ECR prevails as the priority of all respondents regardless of gender, confirming the idea that managers respond, first and above all, to economic commitments. Moreover, the overall hierarchy of priorities is identical in both genders, with ECR prevailing over LER and LER prevailing over ETR. 
TABLE 4 Social Commitment Index Analysis of Variance

\begin{tabular}{|c|c|c|c|c|}
\hline & Obs. (N) & Mean & $\mathrm{DP}$ & Sig. \\
\hline \multicolumn{5}{|l|}{ Gender } \\
\hline Male & 144 & 8.31 & 0.86 & \multirow[t]{2}{*}{$0.009^{*}$} \\
\hline Female & 102 & 8.65 & 0.84 & \\
\hline \multicolumn{5}{|l|}{ Age } \\
\hline$\leq 33$ years & 142 & 8.43 & 0.83 & \multirow[t]{2}{*}{0.660} \\
\hline$\geq 34$ years & 104 & 8.48 & 0.89 & \\
\hline \multicolumn{5}{|l|}{ Professional Experience } \\
\hline$\leq 10$ years & 128 & 8.43 & 0.70 & \multirow[t]{2}{*}{0.515} \\
\hline$\geq 11$ years & 118 & 8.50 & 0.87 & \\
\hline \multicolumn{5}{|l|}{ Academic Background } \\
\hline Business & 114 & 8.56 & 0.75 & \multirow[t]{3}{*}{0.194} \\
\hline Engineering & 40 & 8.41 & 0.91 & \\
\hline Others & 94 & 8.34 & 0.82 & \\
\hline \multicolumn{5}{|l|}{ Functional Background } \\
\hline General Management & 34 & 8.45 & 0.79 & \multirow[t]{6}{*}{0.511} \\
\hline Finance & 52 & 8.42 & 0.78 & \\
\hline Marketing & 45 & 8.28 & 0.85 & \\
\hline Human Resources & 33 & 8.51 & 0.95 & \\
\hline Production & 14 & 8.24 & 0.90 & \\
\hline Other & 68 & 8.60 & 0.89 & \\
\hline \multicolumn{5}{|l|}{ Hierarchical Level } \\
\hline Upper Management & 40 & 8.49 & 0.79 & \multirow[t]{3}{*}{0.826} \\
\hline Middle Management & 84 & 8.43 & 0.83 & \\
\hline Lower Management & 122 & 8.45 & 0.94 & \\
\hline \multicolumn{5}{|l|}{ Type of Business } \\
\hline Commerce & 24 & 8.54 & 0.89 & \multirow[t]{3}{*}{0.484} \\
\hline Services & 185 & 8.47 & 0.65 & \\
\hline Industry & 37 & 8.30 & 0.97 & \\
\hline \multicolumn{5}{|l|}{ Company Size } \\
\hline Small \& Medium & 92 & 8.46 & 0.83 & \multirow[t]{2}{*}{0.948} \\
\hline Large & 144 & 8.46 & 0.88 & \\
\hline
\end{tabular}

A one-way analysis of variance (ANOVA) was conducted to compare means of each group.

${ }^{*}$ Correlation is significant at the 0.01 level.

Results also reveal a significant influence of age and professional experience on manager's economic and legal responsibilities. Older and more experienced managers give less importance to economic responsibilities and more to legal responsibilities than their younger and less experienced colleagues. Given that no significant differences were found regarding ETR, this result suggests that managers tend to sacrifice the economic commitment in favor of the legal commitment as they grow older and more experienced. This may mean that managers' willingness to sacrifice compliance with the law in favor of economic goals decreases with age and experience. Maturity seems to promote a more legalistic managerial attitude that renounces economic commitments in favor of a greater legal commitment, without, however, sacrificing ethical corporate commitments toward society.

Based on the analysis of the role played by several individual and organizational demographic factors, it is possible to conclude that only personal 
TABLE 5 Corporate Social Responsibilities Means and Analysis of Variance

\begin{tabular}{|c|c|c|c|c|c|c|}
\hline & \multicolumn{2}{|c|}{ ECR } & \multicolumn{2}{|c|}{ LER } & \multicolumn{2}{|c|}{ ETR } \\
\hline & Mean & Sig. & Mean & Sig. & Mean & Sig. \\
\hline \multicolumn{7}{|l|}{ Gender } \\
\hline Male & 4.01 & \multirow[t]{2}{*}{0.107} & 3.30 & \multirow[t]{2}{*}{$0.044^{*}$} & 2.74 & \multirow[t]{2}{*}{$0.000^{* *}$} \\
\hline Female & 3.85 & & 3.09 & & 3.07 & \\
\hline \multicolumn{7}{|l|}{ Age } \\
\hline$\leq 33$ years & 4.08 & \multirow[t]{2}{*}{$0.001^{* *}$} & 3.09 & \multirow[t]{2}{*}{$0.009^{* *}$} & 2.83 & \multirow[t]{2}{*}{0.260} \\
\hline$\geq 34$ years & 3.75 & & 3.31 & & 2.94 & \\
\hline \multicolumn{7}{|l|}{ Professional Experience } \\
\hline$\leq 10$ years & 4.06 & \multirow[t]{2}{*}{$0.006^{* *}$} & 3.10 & \multirow[t]{2}{*}{$0.014^{*}$} & 2.84 & \multirow[t]{2}{*}{0.367} \\
\hline$>11$ years & 3.74 & & 3.30 & & 2.93 & \\
\hline \multicolumn{7}{|l|}{ Academic Background } \\
\hline Business & 3.92 & \multirow{3}{*}{0.137} & 3.15 & \multirow{3}{*}{0.312} & 2.92 & \multirow{3}{*}{0.134} \\
\hline Engineering & 4.13 & & 3.20 & & 2.67 & \\
\hline Others & 3.83 & & 3.18 & & 2.95 & \\
\hline \multicolumn{7}{|l|}{ Functional Area } \\
\hline General Management & 3.98 & \multirow[t]{6}{*}{0.717} & 3.19 & \multirow[t]{6}{*}{0.679} & 2.84 & \multirow[t]{6}{*}{0.884} \\
\hline Finance & 4.00 & & 3.16 & & 2.84 & \\
\hline Marketing & 4.05 & & 3.08 & & 2.88 & \\
\hline Human Resources & 4.01 & & 3.11 & & 2.88 & \\
\hline Production & 3.92 & & 3.31 & & 2.66 & \\
\hline Other & 3.80 & & 3.25 & & 2.95 & \\
\hline \multicolumn{7}{|l|}{ Hierarchical Level } \\
\hline Upper Management & 3.92 & \multirow[t]{3}{*}{0.890} & 3.35 & \multirow[t]{3}{*}{0.091} & 2.75 & \multirow[t]{3}{*}{0.262} \\
\hline Middle Management & 3.87 & & 3.31 & & 2.82 & \\
\hline Lower Management & 3.97 & & 3.10 & & 2.95 & \\
\hline \multicolumn{7}{|l|}{ Type of Business } \\
\hline Commerce & 3.88 & \multirow[t]{3}{*}{0.850} & 2.87 & 0.171 & 3.15 & 0.138 \\
\hline Services & 3.94 & & 3.22 & & 2.84 & \\
\hline Industry & 3.99 & & 3.11 & & 2.90 & \\
\hline Company Size & & & & & & \\
\hline Small \& Medium & 3.97 & 0.617 & 3.22 & 0.508 & 2.81 & 0.247 \\
\hline Large & 3.92 & & 3.16 & & 2.92 & \\
\hline
\end{tabular}

A one-way analysis of variance (ANOVA) was conducted to compare means of each group.

${ }^{* *}$ Correlation is significant at the 0.01 level.

${ }^{*}$ Correlation is significant at the 0.05 level.

characteristics, such as age and gender, exert significant influence on management attitudes toward CSR. As shown on Table 5, manager's academic background, functional area, hierarchical position, company size, and type of business do not appear to have a significant impact on the structure of managers' attitudes.

\section{CONCLUSION}

The purpose of this research was to study Brazilian managers' social commitment; that is, their willingness to adopt socially responsible management 
practices. Given the ambiguity and conceptual dispersion that still surrounds CSR, an approach was proposed based on concepts relating to the sources of social responsibility. CSR was thus defined as the set of obligations that commit business corporations to society, disaggregated in three levels of social responsibility: economic, legal, and ethical. Thus, a socially responsible management attitude is one that shows a willingness to combine and respect these three commitments into practical managerial choices. In order to measure the degree of managers' social commitment, a new scale was presented and tested; based on this, the managers' Social Commitment Index (SCI) was proposed. To stud managers' preferences and test the validity of the new scale, a field research was undertaken with 252 Brazilian managers.

The analysis of the empirical data confirmed the consistency of the subscales built to measure Economic Responsibility (ECR), Legal Responsibility (LER), and Ethical Responsibility (ETR). Based on these indicators, results suggested that surveyed managers prioritize economic commitments to a greater extent than legal and ethical social commitments, with fulfillment of the latter two being to the detriment of ECR. Results also showed that managers' SCI tend to increase as they give more importance to LER and, even more, to ETR, with the inevitable sacrifice of ECR. This means, as expected, that socially responsible management attitudes are associated with the preference of corporate non-economic commitments. In addition, analysis of attitudes toward ECR, LER, and ETR relative to demographic factors revealed that as managers get older and their professional experience increases, they tend to become progressively more legalistic, compromising more easily the economic commitment in favor of compliance with the law. The results further showed that men are, generally, more legalistic than women, with the latter showing greater sensibility than men to the ethical commitments that bind business corporations to society at large.

Furthermore, results suggest that specific corporate characteristics and managers' professional circumstances do not influence the way they face CSR demands and underlying social commitments. CSR requires from managers a philosophical approach that sustains their practical responses when faced with executive, as well as strategic, management dilemmas. Thus, their choices evoke personal principles and values, grounded rather more on their human than on their professional condition. This in itself is an important hint with regards to the essentially ethical nature of the rationale and the fundamentals that nurture, challenge, and justify CSR debate.

In sum, managers' attitudes toward CSR appear, as expected, to be essentially dependent on management bonds toward economic results and their accountability toward shareholder interests, often opposed to public interest. Personal and professional maturity tends to weaken this bond in favor of a greater legal commitment, possibly suggesting a decreased willingness to assume risks or a greater awareness of LER as an important social responsibility. Finally, women seem generally more willing to incorporate societal interests 
into management decision making, thus revealing a better adjusted attitude to the multiple demands required by socially responsible management.

The understanding of CSR based on three social commitments and the proposal of a new scale to measure managers' social commitment are the main contributions of this research. The empirical study has validated the scale, confirming its practical relevance and theoretical adjustment, contributing as well to a broader understanding of how Brazilian managers' attitudes are structured with respect to the highly demanding commitments underlying CSR. Additional studies with other managers, culturally, economically, and geographically diverse, should be conducted in order to confirm or improve the scale's adequacy for understanding CSR actual implications and challenges.

\section{NOTES}

1. This interdependence is especially visible in the second half of the twentieth century, after the Second World War, when, as stated by Bittencourt and Carrieri (2005: 13), "the failure of liberalism caused a philosophical vacuum (...), implying a rupture with the social theory that established the convergence of private and social interests as a whole."

2. This hierarchy was confirmed in empirical studies (Aupperle et al., 1985).

3. The Philanthropic responsibility mentioned by Carroll is justified by the fact that the author anchors his thought in North American reality, characterized by a deep-seated philanthropic tradition, which makes of philanthropy an actual societal expectation as regards to corporate practice, becoming a true category of a social responsibility. However, the author himself acknowledges that, although desirable and socially valued, Philanthropic responsibility is less important than the remaining three social responsibilities (Carroll, 1991).

4. In a comprehensive analysis on CSR literature published over a 30-year period (1972-2002), Carroll emerges as the most productive author (with 10 published papers) and the article by Aupperle et al. (1985) emerges as the most cited (Bakker et al., 2005). The scale developed by the authors remains one of the instruments most often used to study corporate social orientation and business leaders' attitudes toward CSR (Acar et al., 2001).

5. Stakeholders' demands are the materialization of societal expectations with respect to corporate performance, defining the scope of its social responsibilities (Bakker et al., 2005). This justifies using stakeholder interests as a reference for socially responsible management practice.

6. In a general indicator such as the SCI intends to be, there is no reason to value differently any of the social commitments within the CSR construct. Therefore, the greater difference between ECR, LER, and ETR represents a valid measure of the distance each manager is from equal value all the social responsibilities (the less pronounced difference among these responsibilities is, in these terms, irrelevant, as it is overlapped by the greater difference).

7. Being a forced choice scale, negative correlations were expected. However, it was not mandatory that ECR would distinguish this clearly from the others, this being the theoretically most relevant result. This interesting result of an apparent opposition between LER and ETR should be addressed in further studies, as it falls outside the remit of this paper.

8. After analyzing histograms and box plot graphs of the SCI variable, six outliers were identified and excluded.

\section{REFERENCES}

Acar, W., Aupperlle, K., and Lowy, R. (2001). "An Empirical Exploration of Measures of Social Responsibility across the Spectrum of Organizational Types," The International Journal of Organizational Analysis, Vol. 9, No. 1, pp. 26-57. 
Aguilar, F. (1996). A Ética nas Empresas: Maximizando Resultados Através de uma Conduta Ética nos Negócios. Traduçẫo Ruy Jungmann. Rio de Janeiro: Jorge Zahar Editor.

Angus-Leppan, M. L., and Benn, S. (2009). "Leadership Styles and CSR Practice: An Examination of Sensemaking, Institutional Drivers and CSR Leadership," Journal of Business Ethics, Vol. 93, pp. 189-213.

Ashley, P. (Ed.). (2005). Ética e Responsabilidade Social nos Negócios. 2nd ed. São Paulo: Saraiva.

Aupperle, K., Carroll, A., and Hatfield, J. (1985). "An Empirical Investigation of the Relationship between Corporate Social Responsibility and Profitability," Academy of Management Journal, Vol. 28, No. 2, pp. 446-463.

Bakker, F., Groenewegen, P., and Hond, F. (2005). "A Bibliometric Analysis of 30 Years of Research and Theory on Corporate Social Responsibility and Corporate Social Performance," Business \& Society, Vol. 44, No. 3, pp. 283-317.

Bittencourt, E., and Carrieri, A. (2005). "Responsabilidade Social: Ideologia, Poder e Discurso na Lógica Empresarial," Revista de Administração de Empresas, Vol. 45, pp. 10-22, Special Edition Minas Gerais.

Blasco, M., and Zolner, M. (2010). "Corporate Social Responsibility in Mexico and France: Exploring the Role of Normative Institutions," Business and Society, Vol. 49, No. 2, pp. 216-251.

Boatright, J. (2003). Ethics and the Conduct of Business. 4th ed. New Jersey: Prentice Hall. Byrne, B. (1998). Structural Equation Modeling with LISREL, PRELIS and SIMPLIS: Basic Concepts, Applications and Programming. New Jersey: Lawrence Erlbaum Associates, Inc.

Carroll, A. (1979). "Three-Dimensional Conceptual Model of Corporate Social Performance," Academy of Management Review, Vol. 4, pp. 497-505.

Carroll, A. (1991). "The Pyramid of Corporate Social Responsibility: Toward the Moral Management of Organizational Stakeholders," Business Horizons, Vol. 34, No. 4, pp. 39-48.

Carroll, A. (1999). "Corporate Social Responsibility: Evolution of a Definitional Construct," Business \& Society, Vol. 38, No. 3, pp. 268-295.

Davis, K. (1973). "The Case For and Against Business Assumption of Social Responsibilities," Academy of Management Journal, Vol. 16, pp. 312-322.

Diamantopoulos, A., and Siguaw, J. (2000). Introducing LISREL. London: Sage.

Eisenhardt, K. (1989). "Agency Theory: An Assessment and Review," Academy of Management Review, Vol. 14, No. 1, pp. 57-74.

Fernández-Kranz, D., and Santaló, J. (2010). "When Necessity Becomes a Virtue: The Effect of Product Market Competition on Corporate Social Responsibility," Journal of Economics \& Management Strategy, Vol. 19, No. 2, pp. 453-487.

Ferrell, O., Fraedrich, J., and Ferrell, L. (2002). Business Ethics: Ethical Decision Making and Cases. 5th ed. Boston: Houghton Mifflin Company.

Fornell, C., and Larcker, D. (1981). "Evaluating Structural Equation Models with Unobserved Variables and Measurement Error," Journal of Marketing Research, Vol. 18, No. 1, pp. 39-50.

Frederiksen, C. (2009). "The Relation Between Policies Concerning Corporate Social Responsibility (CSR) and Philosophical Moral Theories-An Empirical Investigation," Journal of Business Ethics, Vol. 93, pp. 357-371. 
Friedman, M. (1962). Capitalism and Freedom. Chicago: University of Chicago Press.

Froes, F. (2001). Gestão da Responsabilidade Social Corporativa: O Caso Brasileiro. Rio de Janeiro: Qualitymark Ed.

Godfrey, P., Hatch, N., and Hansen, J. (2010). "Toward a General Theory of CSRs: The Roles of Beneficence, Profitability, Insurance, and Industry Heterogeneity," Business and Society, Vol. 49, No. 2, pp. 316-344.

Hemingway, C. (2005). "Personal Values as a Catalyst for Corporate Social Entrepreneurship," Journal of Business Ethics, Vol. 60, pp. 233-249.

Houaiss, A., and Villar, M. (2002). Dicionário Houaiss da Lingua Portuguesa. Rio de Janeiro: Instituto Antônio Houaiss de Lexicografia.

Ibrahim, N., and Angelidis, J. (1993). "Corporate Social Responsibility: A Comparative Analysis of Perceptions of Top Executives and Business Students," The Mid-Atlantic Journal of Business, Vol. 29, No. 3, pp. 303-314.

Instituto Ethos. O que é a Responsabilidade Social Empresarial? Available: <http:// www.ethos.org.br>. Accessed: May 6, 2009.

Joreskog, K., and Sorbom, D. (1996). LISREL 8: User's Reference Guide. Illinois: Scientific Software International.

Karkotli, G., and Aragão, S. (2005). Responsabilidade Social: Uma Contribuição à Gestão Transformadora das Organizações. 2nd ed. Petrópolis, RJ: Vozes.

Kisil, M. (2005). Comunidade: Foco de Filantropia e Investimento Social Privado. São Paulo: Global Editora; Porto Alegre: IDIS-Instituto para o Desenvolvimento do Investimento Social.

Kreitlon, M. (2004). "A Ética nas Relações entre Empresas e Sociedade: Fundamentos Teóricos da Responsabilidade Social Empresarial," Proceedings: XXVIII Encontro da Associação Nacional de Pós-Graduação e Pesquisa em Administração, Curitiba. Rio de Janeiro: ANPAD. CD-ROM

Maclagan, P. (1998). Management and Morality. London: Sage.

McGuire, J. (1963). Business and Society. New York: McGraw-Hill.

Mitchell, R., Agle, B., and Wood, D. (1997). "Toward a Theory of Stakeholder Identification and Salience: Defining the Principle of Who and What Really Counts," Academy of Management Review, Vol. 22, pp. 853-886.

Moore, G. (2001). "Corporate Social and Financial Performance: An Investigation in the U.K. Supermarket Industry," Journal of Business Ethics, Vol. 34, pp. 299-315.

Pinto, M., Pereira, D., and Lara, J. (2004). "Caracterização de Perfis de Empresas quanto à Adoção de Práticas de Responsabilidade Social," Proceedings: XXVIII Encontro da Associação Nacional de Pós-Graduação e Pesquisa em Administração, Curitiba. Rio de Janeiro: ANPAD. CD-ROM

Puncheva-Michelotti, P., Michelotti, M., and Gahan, P. (2009). "The Relationship Between Individuals' Recognition of Human Rights and Responses to Socially Responsible Companies: Evidence from Russia and Bulgaria," Journal of Business Ethics, Vol. 93, pp. 583-605.

Puppim de Oliveira, J. (2005). "Uma Avaliação dos Balanços Sociais das 500 Maiores," RAE eletrônica, Vol. 4, No. 1, paper 2.

Roman, R., Hayibor, S., and Agle, B. (1999). "The Relationship between Social and Financial Performance," Business E Society, Vol. 38, No. 1, pp. 109-125. 
Shafer, W., Fukukawa, K., and Lee, G. (2006). "Values and the Perceived Importance of Ethics and Social Responsibility: The U.S. versus China," Journal of Business Ethics, Vol. 70, pp. 265-284.

Simpson, W., and Kohers, T. (2002). "The Link Between Corporate Social and Financial Performance: Evidence from the Banking Industry," Journal of Business Ethics, Vol. 35, pp. 97-109.

Sirsly, C. (2009). "75 Years of Lessons Learned: Chief Executive Officer Values and Corporate Social Responsibility," Journal of Management History, Vol. 15, No. 1, pp. 78-94.

Tengblad, S., and Ohlsson, C. (2009). "The Framing of Corporate Social Responsibility and the Globalization of National Business Systems: A Longitudinal Case Study," Journal of Business Ethics, Vol. 93, pp. 653-669.

Tenório, F. (Ed.). (2004). Responsabilidade Social Empresarial: Teoria e Prática. Rio de Janeiro: Editora FGV.

Thiry-Cherques, H. (2003). "Responsabilidade Moral e Identidade Empresarial," Revista de Administração Contemporânea, Edição Especial, pp. 31-50.

Verschoor, C. (1998). "A Study of the Link between a Corporation's Financial Performance and Its Commitment to Ethics," Journal of Business Ethics, Vol. 17, pp. 1509-1516.

$\mathrm{Xu}, \mathrm{S}$., and Yang, R. (2009). "Indigenous Characteristics of Chinese Corporate Social Responsibility Conceptual Paradigm," Journal of Business Ethics, Vol. 93, pp. 321-333.

Walton, C. (1967). Corporate Social Responsibilities. Belmont, CA: Wadsworth.

Wartick, S., and Cochran, P. (1985). "The Evolution of the Corporate Social Performance Model," Academy of Management Review, Vol. 10, pp. 758-769.

Wood, D. (1991). "Corporate Social Performance Revisited," Academy of Management Review, Vol. 16, No. 4, pp. 691-718. 